\title{
THE FRESHWATER CRAYFISH AUSTROPOTAMOBIUS PALLIPES IN SOUTH TYROL: HERITAGE SPECIES AND BIOINDICATOR
}

\author{
L. FÜREDER (1), B. OBERKOFLER (1), R. HANEL (2), J. LEITER (1), B. THALER (3)
}

(1) University of Innsbruck, Institute of Zoology and Limnology, Technikerstr. 25, A-6020 Innsbruck, Austria.

E-Mail: leopold.fuereder@uibk.ac.at

(2) Institut für Meereskunde Kiel, Marine Ökologie - Fischereibiologie, Düsternbrooker Weg 20, D-24105 Kiel, Germany.

(3) Autonome Provinz Bozen, Biologisches Landeslabor, Unterberg 2, I-39055 Leifers, Italy.

Reçu en septembre 2003

Received September 2003

Accepté le 18 mars 2004

Accepted March 18, 2004

\begin{abstract}
Rapid decline of crayfish in European freshwaters and continuing threat necessitate integrated actions in conservation and management of native crayfish populations. Besides biological reasons (diseases, plague), the impact of toxic and harmful substances (fertilisers, herbicides) or wastewater effluents, habitat alteration or fragmentation have been responsible for their decline in some regions. The same is true for the region of South Tyrol, where compared to previous investigations, only 10 of a former total of 15 crayfish locations in the water bodies could be affirmed. Although two new populations of the non-indigenous Astacus astacus were detected, the native Austropotamobius pallipes continues to decline. While many investigations have focused accurately on causal coherences for the decline of native populations, the properties of crayfish facilitate to reverse the situation. In a few examples, the potential of Austropotamobius pallipes, the native crayfish in South Tyrol, as "surrogate species" for effective biological conservation is discussed. Given the various adequate attributes of freshwater crayfish as surrogate species (including indicator species, umbrella species and flagship species qualities), they may help to advance not only the crayfish situation itself but also freshwater ecosystem properties in general.
\end{abstract}

Key-words: focal species, flagship species, surrogate species, nature conservation, species protection.

\section{L'ÉCREVISSE AUSTROPOTAMOBIUS PALLIPES DANS LE TYROL DU SUD : ESPÈCE PATRIMONIALE ET BIOINDICATEUR}

\section{RÉSUMÉ}

Le déclin rapide des populations d'écrevisses dans les eaux continentales européennes ainsi que la menace permanente subie par ces populations nécessitent des actions intégrées pour une conservation et une gestion des populations d'écrevisses natives. Outre les causes biologiques (maladies, peste), l'impact des substances toxiques et dangereuses (fertilisants, herbicides) ou des effluents d'eaux usées, l'altération de 
I'habitat ou la fragmentation sont responsables de leur déclin dans quelques régions. C'est également valable pour la région du sud du Tyrol, où, après comparaison avec des études précédentes, seulement dix sites sur quinze répertoriés peuvent être actuellement confirmés. Bien que deux nouvelles populations de l'espèce non-native d'Astacus astacus aient été trouvées, celles de l'espèce patrimoniale Austropotamobius pallipes continuent donc de régresser. Alors que beaucoup d'investigations se sont portées précisément sur les arguments expliquant le déclin des populations natives, les capacités de l'écrevisse lui permettent de retourner la situation. A partir de quelques exemples, le potentiel de Austropotamobius pallipes, espèce patrimoniale dans le sud du Tyrol, en tant que " espèce de substitution » pour une conservation biologique est discutée. Étant donné les différentes qualités adéquates de l'écrevisse en tant qu'espèce de substitution (incluant les qualités d'espèce indicatrice, d'espèce parapluie, et d'espèce amirale), ceci peut mener non seulement à une avancée pour une gestion des écrevisses elles-mêmes mais aussi de l'écosystème d'eau douce dans son ensemble.

Mots-clés : espèce focale, espèce amirale, espèce de substitution, conservation de la nature, espèce protégée.

\section{INTRODUCTION}

Aquatic environments are highly dependent on catchment properties. Morphology and ecosystem function often reflect land-use practises and state of development or degree of industrialisation of a region. In mountainous areas like the Alps, colonisation combined with agriculture, industrialisation and traffic route development has been concentrated in habitable, cultivable and accessible land. All together, they have posed a great variety of threats on the available natural ecosystems. As a consequence, freshwater systems have experienced multiple alterations in these densely populated areas, like river regulation, habitat fragmentation and water abstraction (DYNESIUS and NILSSON, 1994), together responsible for habitat loss and depletion in the Alpine region (FÜREDER et al., 2002a).

Changes of water quality, ecosystem health or ecosystem integrity have often been recorded by assessing assemblages of bioindicator species like fish and macroinvertebrates or by monitoring water or sediment chemistry (MOOG and CHOVANEC, 2000; ÖNORM M 6232, 1995). Although widely applied throughout Europe, disadvantages of using macroinvertebrates (e.g., aquatic insects) in water quality assessments are that assemblages may vary from place to place, information on species distribution is still fragmentary, and monitoring activities are labour and cost intensive. Only a few species are found throughout a wide range of habitat across Europe, causing water quality monitoring to be national rather than international. An auspicious alternative approach may therefore be the use of a keystone species (-group) widely distributed and well known in Europe (e.g., HOLDICH, 2002). In freshwaters, the largest active and long-lived invertebrates are freshwater crayfish, which have received some attention in European countries as attractive animals for recreational fishing (SKURDAL and TAUGBOL, 2001), in some regions over several hundred years. Historical evidence is provided for some countries demonstrating also their cultural value (as a lenten meal or delicacy at feasts, FÜREDER and MACHINO 1999a).

As in many endangered species, the decrease of native freshwater crayfish in European countries as well as acute threats have been portrayed as a consequence of human activities (GHERARDI and HOLDICH, 1999; SKURDAL and TAUGBOL, 2001; FÜREDER et al., 2002c), usually attributed to epizootic fungal disease (the crayfish plague, Aphanomyces astaci Schikora, a fungus formerly endemic to North America but introduced to Europe towards the end of the $19^{\text {th }}$ century, see ACKEFORS (2000)), but also to the multiple degradation of rivers and lakes by human activities. 
Direct effects on crayfish in addition to inexperienced or careless crayfish management (stocking of allochthonous species) still cause the decline of autochthonous crayfish populations in several European regions (BÜTTIKER, 1987; BOHL, 1999; FÜREDER and MACHINO, 1999a; FÜREDER and HANEL, 2000; GHERARDI et al., 1999). Accordingly, in Austria both the noble crayfish Astacus astacus (Linnaeus, 1758), recorded in North/East Tyrolean waters since the Middle Ages (FÜREDER and MACHINO, 1999a), and the autochthonous stone crayfish Austropotamobius torrentium (Schrank, 1803) are considered as highly endangered species (PRETZMANN, 1994). In the Italian province of South Tyrol (Autonome Provinz Bozen) the autochthonous white-clawed crayfish Austropotamobius pallipes (Lereboullet, 1858) was also reported to be highly threatened (BALDASSI, 1993; ADAMI and GASSER, 1994; HELLRIGL and THALER, 1996).

FÜREDER and MACHINO (1999a) provided the most complete historical information on previous records. From these data, one may conclude that freshwater crayfish were formerly more widely distributed and crayfish locations were found in many lakes, brooks, and rivers throughout North/East Tyrol and South Tyrol till the beginning of the $20^{\text {th }}$ century. They also found evidence on vital trades between countries as well as regions, providing individual water bodies with economic value. The above mentioned effects on habitats and native populations over the last two centuries, led to a decrease in interest by man in these previously appreciated animals.

In recent investigations we have been focusing on the present situation of freshwater crayfish and the level of threats (FÜREDER and HANEL, 2000; FÜREDER et al., 2002b) in Tyrol, where until the end of last century only little written information on freshwater crayfish was available (see FÜREDER et al., 2002c). Our goals in this paper were to: (1) highlight the alarming and still ongoing decline of native freshwater crayfish in the Italian province of South Tyrol, (2) provide the information we collected on the few existing but highly endangered populations in South Tyrol and (3) show and discuss how threatened freshwater crayfish species can be used to address scientific and management issues for protection measures.

\section{MATERIAL AND METHODS}

Tyrol is composed of three parts, divided by the Austrian-Italian border (Figure 1), i.e. North Tyrol (Austrian Tyrol, except the Drave basin), East Tyrol (Austrian Tyrol of the Drave basin), and South Tyrol (Italian Tyrol, Autonome Provinz Bozen). To provide information on the present crayfish situations in the Austrian and Italian Tyrols, data from fieldwork carried out in summer 2000 and 2001 in South Tyrol are compared to historical data and results from earlier fieldwork, and for completeness, results from North and East Tyrol (FÜREDER and HANEL, 2000) are included in the present analysis.

Historical and recent information on crayfish locations were collected through comprehensive literature and data research (preliminary results were taken from FÜREDER and Machino, 1999a) and used as a base for the inventories and succeeding investigations (more details are given in FÜREDER et al., 2002b). In order to obtain additional information on potential crayfish sites, a questionnaire was sent to responsible governmental departments, environmental agencies, fishery authorities, owners, and tenants of lakes and fishing rights, as well as various other people.

In the identified regions potentially holding crayfish, running and standing waters known and/or suspected to hold freshwater crayfish were investigated, mainly during the warm months. The water bodies were first assessed by describing their ecological status, habitat condition, and existing impacts, adapted from assessment forms by BOHL (1989) and FÜREDER et al. (2002a). Details on habitat characteristics are summarized in 


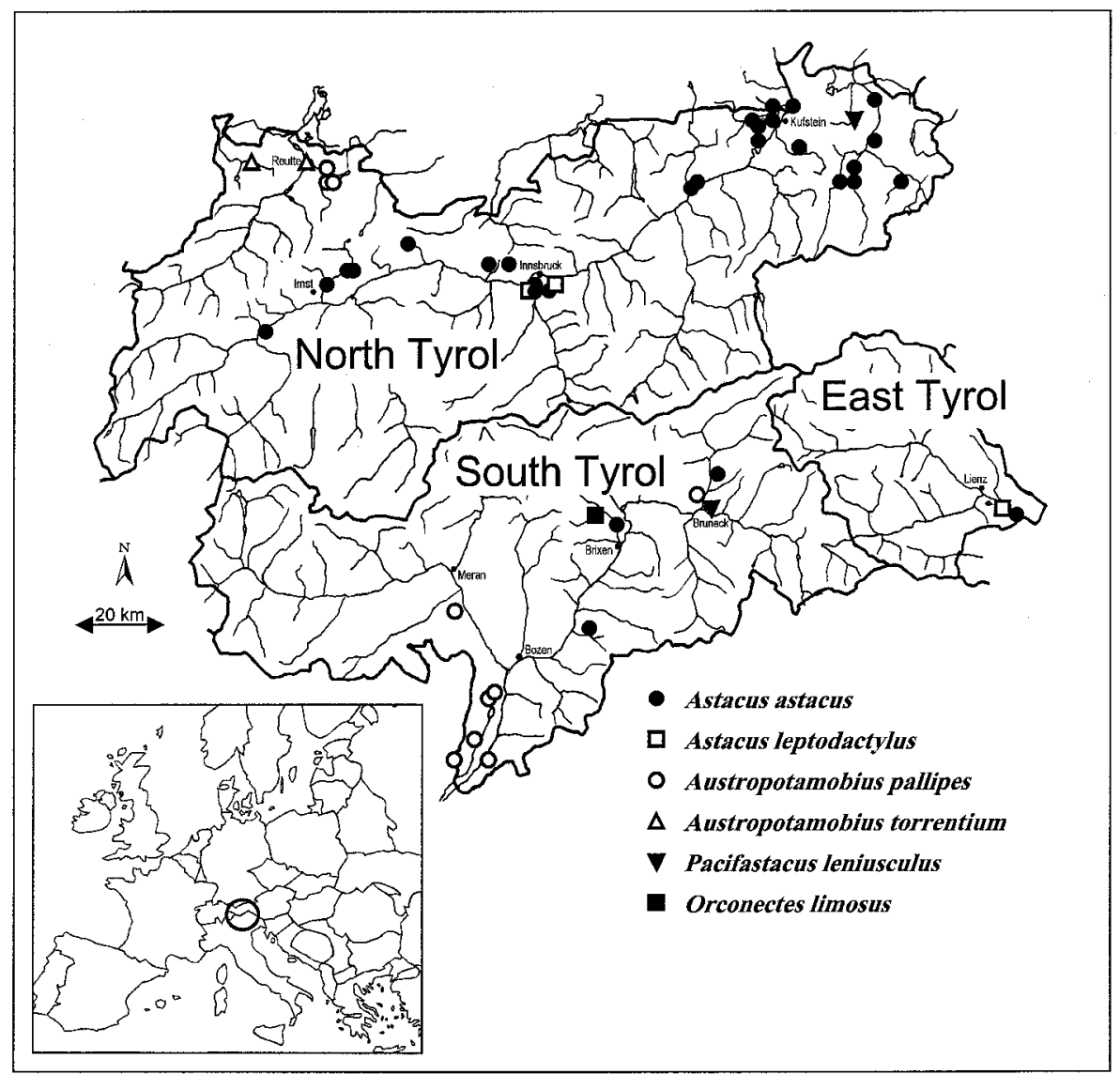

Figure 1

Present distribution of freshwater crayfish in South Tyrol compared to species and sites in North/East Tyrol. Some symbols may cover others, therefore underestimating the actual numbers (especially Astacus astacus in North Tyrol).

Figure 1

Distribution actuelle des écrevisses présentes dans le Sud du Tyrol comparée à celle des espèces et sites du Nord-Est du Tyrol. Les symboles peuvent en masquer d'autres : il en résulte donc une sous-estimation des chiffres actuels (en particulier Astacus astacus dans le Nord du Tyrol).

Table 1. Collecting methods used were various, depending on type, size and depth of the water body or sampling reach. They were performed generally by observations and hand catches during the night but where waters were too deep, crayfish traps were fished for one night and emptied the following morning. All results were included in a database and GIS-based distribution maps were produced for each region. Existing data from fieldwork in 1998 and 1999 (FÜREDER et al., 2002b), were verified again and compared to the recent findings.

Habitat and catchment properties were analysed by combining and classifying detailed characteristics into four categories, i.e. A) catchment properties, B) riparian vegetation - bank condition, C) channel morphology and D) substrate (Table 1). 
Table I

Examples of catchment properties and habitat characteristics used for environmental assessments in presented freshwater crayfish inventories; four main categories were summarized for use in Figure 4.

\section{Tableau I}

Exemples de propriétés d'un bassin et de caractéristiques de l'habitat utilisées pour les investigations environnementales dans les inventaires sur les écrevisses; quatre catégories principales sont résumées pour une utilisation dans la figure 4.

\begin{tabular}{lcl}
\hline Main Category & \# of parameters & Comments \\
\hline Catchment properties & 15 & $\begin{array}{l}\text { Natural or anthropogenically altered } \\
\text { vegetation, land use, settlements and } \\
\text { industries; areal coverage, distance to } \\
\text { freshwaters }\end{array}$ \\
$\begin{array}{lll}\text { Riparian vegetation } \\
\text { - bank condition }\end{array}$ & $\begin{array}{l}\text { Width, height and structure of riparian } \\
\text { corridor; riparian forest, shrubs, } \\
\text { meadows; shading; cultivation, erosion }\end{array}$ \\
Channel morphology & 33 & $\begin{array}{l}\text { Gradient, channel form, depth and } \\
\text { width variation, mean and maximum } \\
\text { depth, mean and maximum width, } \\
\text { structural conditions, artificial structures, } \\
\text { connectivity }\end{array}$ \\
& & $\begin{array}{l}\text { Abiotic (grain size, rocks, cobble, etc.) } \\
\text { and biotic (leaf packs, wood, algae, } \\
\text { moss, etc.) substrates; hydrology }\end{array}$ \\
& 20 &
\end{tabular}

\section{RESULTS AND DISCUSSION}

\section{Alarming decrease of autochthonous freshwater crayfish in South Tyrol}

The freshwater crayfish inventories and subsequent investigations resulted in records of five species being found in the Austrian province of North/East Tyrol, while in the Italian province of South Tyrol four species live (Figure 1, Table 2). In North and East Tyrol the noble crayfish Astacus astacus and the stone crayfish Austropotamobius torrentium are considered autochthonous species, and in South Tyrol the white-clawed crayfish Austropotamobius pallipes only. Three allochthonous species occur in North/East Tyrol, i.e., the narrow-clawed crayfish Astacus leptodactylus Eschscholz, 1823, the whiteclawed crayfish $A$. pallipes and the signal crayfish Pacifastacus leniusculus (Dana, 1852); in South Tyrol allochthonous species are the noble crayfish $A$. astacus, the signal crayfish P. leniusculus, and the spiny-cheek crayfish Orconectes limosus (Rafinesque, 1817).

Compared to previous investigations (FÜREDER et al., 2002b), only 10 of a former total of 15 crayfish locations in the water bodies of South Tyrol could be affirmed (Table 2). Most crayfish waters (seven) carried the autochthonous crayfish Austropotamobius pallipes, and one location had Astacus astacus, the first record for noble crayfish for the Italian Tyrol (OBERKOFLER et al., 2002). In the meanwhile, two more $A$. astacus populations are known (Table 3), both of them introduced within the last decade in artificial standing waters (a fishery pond north of Brixen and a private pond at Völser Aicha). Each of the two North American species is still found only in one water body, as already published by MACHINO (1997) and FÜREDER and MACHINO (1999b): O. limosus in Vahrner See, an artificial lake north of the town of Brixen (=Bressanone), and P. leniusculus in the Auenbach (Table 3). 


\section{Table II}

Present freshwater crayfish populations and comparison with results from previous investigations ( ${ }^{*}$ FÜREDER et al., 2002c) and recent studies in neighbouring North/ East Tyrol (** FÜREDER and HANEL, 2000)

Tableau II

Populations d'écrevisses actuelles et comparaison avec les résultats d'investigations antérieures (* FÜREDER et al., 2002c) ainsi que des études récentes menées dans la région voisine du Nord-Est du Tyrol (** FÜREDER and HANEL, 2000)

\begin{tabular}{lccc}
\hline & $\begin{array}{c}\text { Number } \\
\text { of populations } \\
\text { in South Tyrol } \\
\text { (present study) }\end{array}$ & $\begin{array}{c}\text { Number } \\
\text { of populations } \\
\text { in South Tyrol }\end{array}$ & $\begin{array}{c}\text { Number } \\
\text { of populations } \\
\text { in North/East } \\
\text { Tyrol }^{\star *}\end{array}$ \\
\hline A. astacus Linnaeus 1758 & 3 & 1 & 35 \\
A. leptodactylus Eschscholz 1823 & - & - & 3 \\
A. torrentium (Schrank 1803) & - & - & 2 \\
A. pallipes (Lereboullet 1858) & 7 & 12 & 3 \\
P. leniusculus (Dana 1852) & 1 & 1 & 1 \\
O. limosus (Rafinesque 1817) & 1 & 1 & - \\
Total number & $\mathbf{1 2}$ & $\mathbf{1 5}$ & $\mathbf{4 4}$ \\
\hline
\end{tabular}

Owing the mountainous topography of both provinces, freshwater crayfish generally occurred at lower elevations in lakes and rivers of the bigger valleys, where temperature regime and channel stability enable the successful survival of crayfish populations (Figure 2). In South Tyrol, only one location with A. pallipes is situated above $1000 \mathrm{~m}$ a.s.I. (the Krebusbach), six were found between 600 and $1000 \mathrm{~m}$ a.s.l., and five remained between 200 and $600 \mathrm{~m}$ a.s.l.

There tends to be a strong decrease in number of crayfish waters, given that in South Tyrol about 50 locations were recorded in the literature (Figure 2). The comparison with former distribution studies in South Tyrol showed that even within the last two to three decades, the crayfish situation became worse (FÜREDER et al., 2002b), and the new data from present investigation re-emphasizes the ongoing trend. In the different parts of the province, populations either declined or even became extinct (Tables 2 and 3).

Only a few freshwaters carried healthy native populations of $A$. pallipes, i.e., Angelbach, Krebusbach, Hyppolithbach and Ritscherbach and of $A$. astacus, i.e. Wiesenbach (Figure 3). At the remaining sites very small populations of $A$. pallipes occurred, the exotic species $O$. limosus and $A$. leniusculus having established small to medium-sized populations (Table 3).

\section{Catchment properties and habitat characteristics}

The analysis of catchment properties and habitat characteristics in 125 freshwater habitats (predominantly streams and rivers, since few South Tyrolean crayfish occur in standing waters) showed that crayfish locations had predominantly moderate to poor catchment and habitat conditions (Figure 4). In freshwaters of historical crayfish records but now extinct populations, catchment and habitat conditions were even worse. Locations with lacking evidence of crayfish occurrence had somewhat better conditions, perhaps because proportionally more intact than impaired waters were inspected for potential crayfish sites. 


\section{Table III}

Present freshwater crayfish populations (investigation 2000 and 2001) and comments on population decline since 1999 (FÜREDER et al., 2002c) and population size estimates (+ small, ++ median, +++ dense population; - no crayfish)

Tableau III

Populations d'écrevisses recensées actuellement (investigations 2000 et 2001) ; commentaires au sujet du déclin des populations d'après FÜREDER et al. (2002c) et estimation de la taille de ces populations (+ petite, ++ moyenne, +++ dense ; - aucune écrevisse)

\begin{tabular}{|c|c|c|c|}
\hline Location & Species & Comments & Size \\
\hline $\begin{array}{l}\text { Krebsbach - Tschars/ } \\
\text { Galsaun }\end{array}$ & A. pallipes & In 2000 and 2001 no crayfish were found & - \\
\hline $\begin{array}{l}\text { Gießbach - Bad } \\
\text { Kochenmoos }\end{array}$ & A. pallipes & $\begin{array}{l}\text { In summer } 2000 \text { only few individuals (1-0.5 } \\
\left.\text { Ind. } 10 \mathrm{~m}^{-1}\right) \text {, in summer } 2001 \text { no crayfish }\end{array}$ & - \\
\hline Krebsbach - Lana & A. pallipes & No crayfish & - \\
\hline Hyppolithbach & A. pallipes & $\begin{array}{l}\text { Intact population in the upper sector of the } \\
\text { stream }\left(\sim 2 \text { Ind. } \mathrm{m}^{-1}\right)\end{array}$ & ++ \\
\hline $\begin{array}{l}\text { Betonschacht bei Schloss } \\
\text { Englar }\end{array}$ & A. pallipes & $\begin{array}{l}\text { In summer } 2000 \text { only few individuals, in } \\
\text { summer } 2001 \text { no crayfish }\end{array}$ & - \\
\hline Angelbach - Montiggl & A. pallipes & $\begin{array}{l}\text { Very dense population in South Tyrol, also } \\
\text { longest stream stretch with crayfish (almost } \\
800 \mathrm{~m} ; 5 \text { Ind. } \mathrm{m}^{-1} \text { ) }\end{array}$ & +++ \\
\hline Krebsbach - Kaltern & A. pallipes & $\begin{array}{l}\text { Only few individuals, in summer } 2001 \text { only } \\
\text { one found }\end{array}$ & + \\
\hline Ritscherbach & A. pallipes & $\begin{array}{l}\text { Population size difficult to assess, however } \\
\text { endangered }\end{array}$ & ++ \\
\hline $\begin{array}{l}\text { Krebusbach - } \\
\text { Unterfennberg }\end{array}$ & A. pallipes & $\begin{array}{l}\text { Intact population } \\
\left(\sim 2 \text { Ind. } \mathrm{m}^{-1}\right)\end{array}$ & ++ \\
\hline Laager Graben & A. pallipes & Strongly declining population & + \\
\hline Moosbachl & A. pallipes & Small population with 3 Ind. $10 \mathrm{~m}^{-1}$ & + \\
\hline $\begin{array}{l}\text { Edelkrebsbach - } \\
\text { Uttenheim }\end{array}$ & A. astacus & Intact population (2-3 Ind. $\left.\mathrm{m}^{-1}\right)$. & +++ \\
\hline Fischteich obh. Brixen & A. astacus & introduced within last decade & $?$ \\
\hline Privatteich Völser Aicha & A. astacus & introduced within last decade & $?$ \\
\hline Auenbach & P. leniusculus & Small to medium population & ++ \\
\hline Vahrner See & O. limosus & $\begin{array}{l}\text { Small (?) population, however areas } \\
\text { difficult to access may be populated denser }\end{array}$ & $++?$ \\
\hline
\end{tabular}




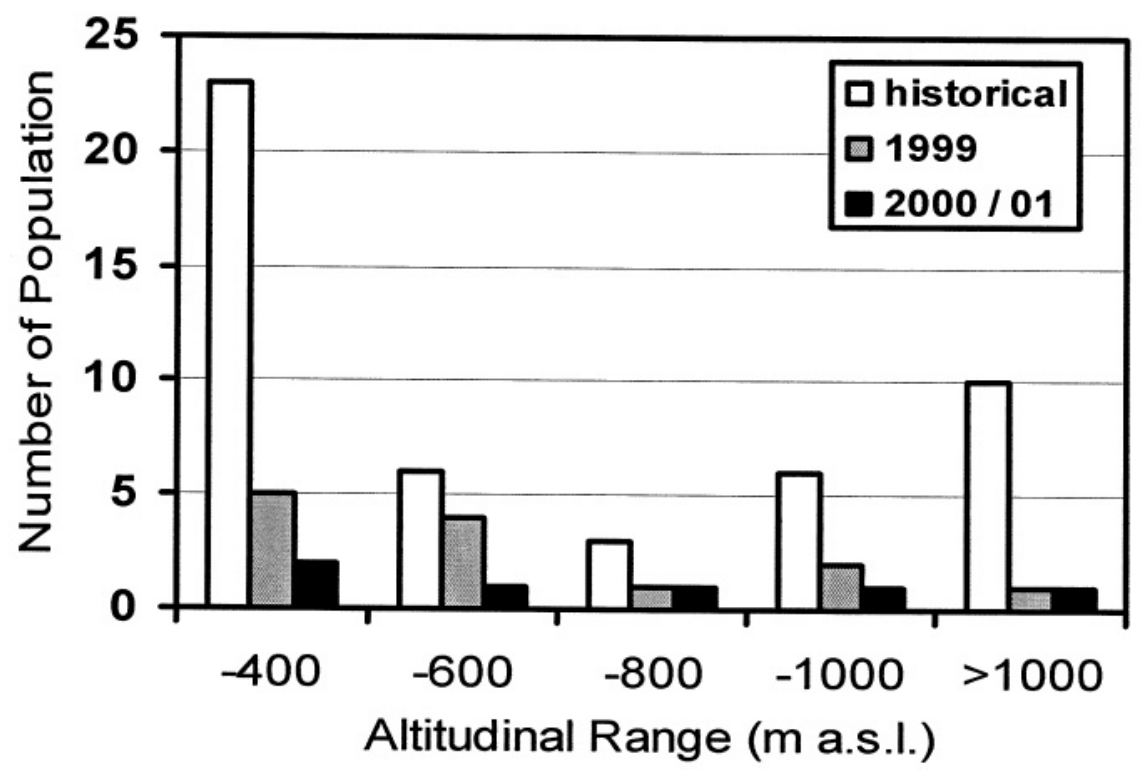

Figure 2

Number of native freshwater crayfish populations (A. pallipes) in South Tyrol and their altitudinal position.

Figure 2

Nombre et altitude des populations d'écrevisses natives dans le Sud du Tyrol.

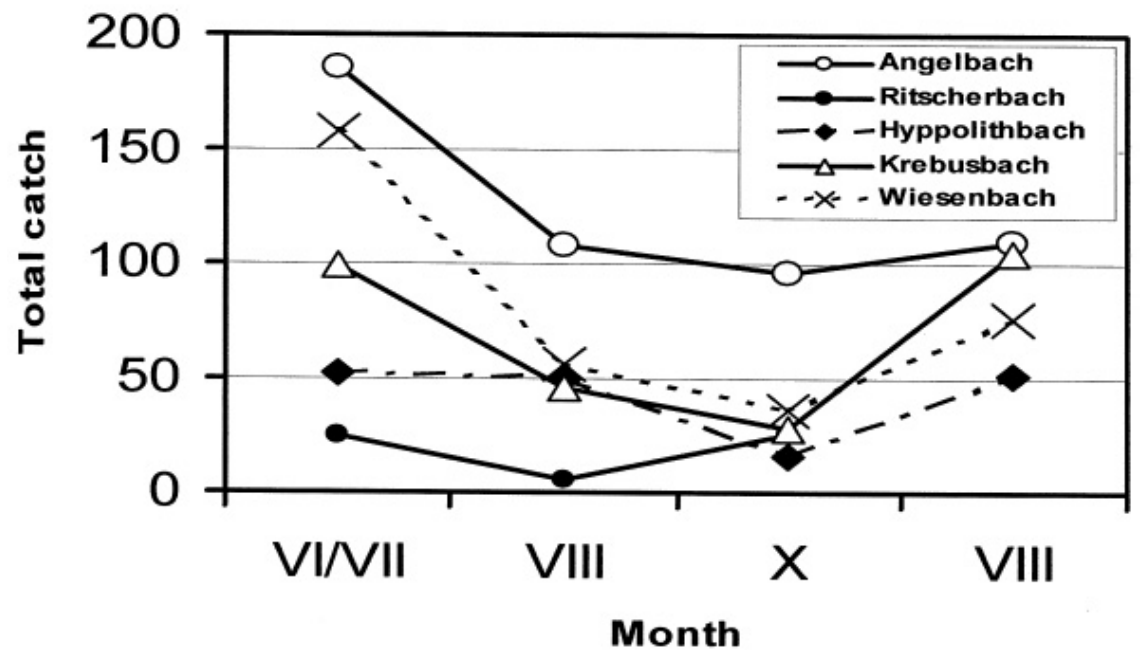

Figure 3

Total catch of freshwater crayfish at four sampling dates (VI/VII, VIII, X in 2000 and VIII in 2001) in remaining crayfish waters with considerable population size.

Figure 3

Prise totale d'écrevisse à quatre dates différentes (VI/VII, VIII, X en 2000 et VIII en 2001) dans des ruisseaux possédant encore des populations de grande taille. 


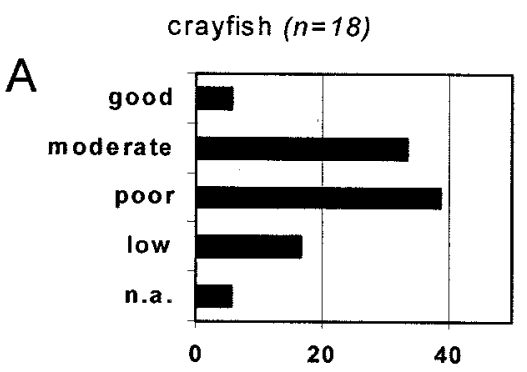

historical $(n=43)$
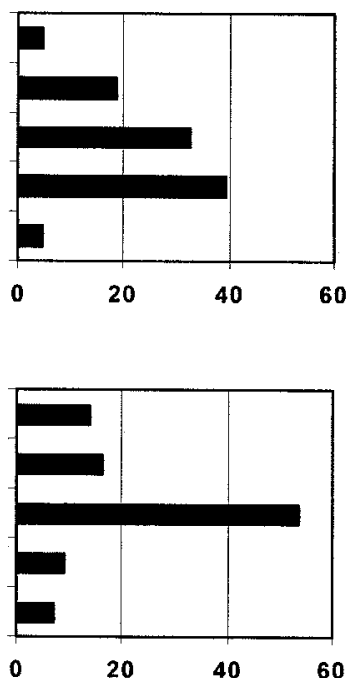

B good moderate

poor low n.a. o

C

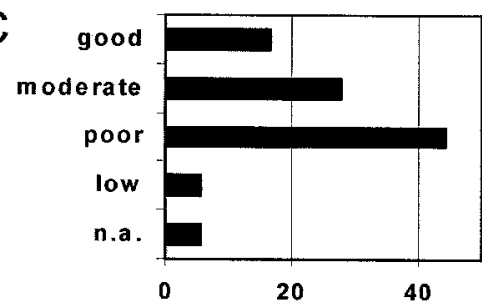

D

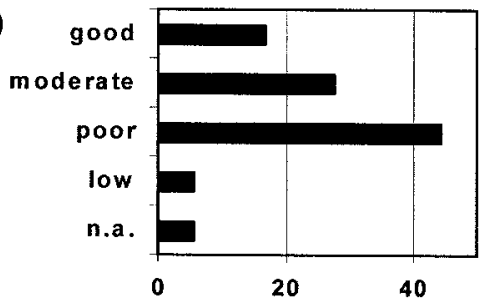

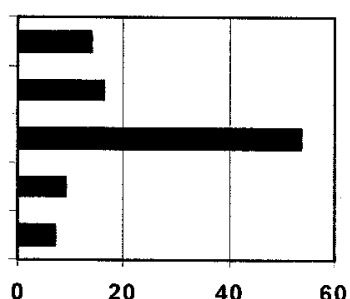
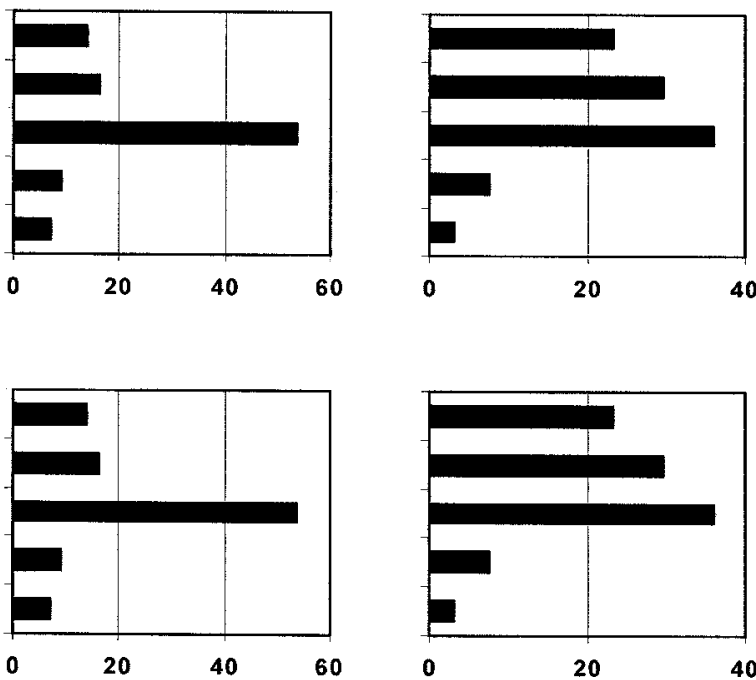

no evidence $(n=64)$
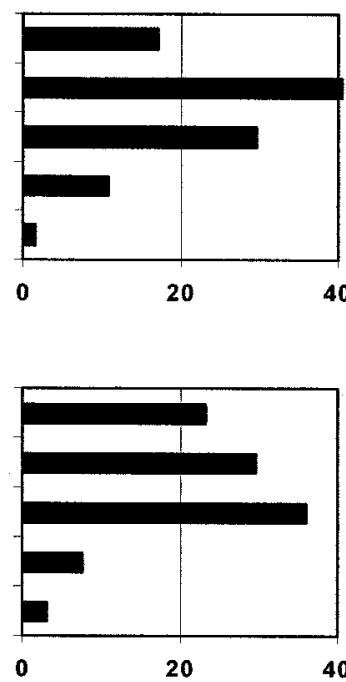

40

Figure 4

Analysis of habitat conditions from a set of 125 stream sectors, 18 with known crayfish populations, 43 with historical data, and 64 without crayfish. $n$ are identifiable different sectors used for analysis (for parameters used see Table 1). Bars indicate the relative abundance of good, moderate, poor or low conditions or characteristics (in percent) of A) catchment properties, B) riparian conditions, C) channel morphology and D) stream bottom structure. n.a. no data available.

Figure 4

Analyse des conditions de l'habitat à partir d'un panel de 125 tronçons de ruisseaux, 18 hébergeant des populations connues, 43 dont on possède des données historiques, et 64 sans écrevisses. $n$ : différents secteurs identifiables et utilisés pour l'analyse (voir Tableau 1 pour les paramètres utilisés). Les barres indiquent l'abondance relative de bonnes, modérées, pauvres ou faibles conditions ou caractéristiques (en pourcentage) de A) propriétés du bassin, B) conditions ripariennes, C) morphologie du canal et D) structure du fond du ruisseau. n.a. pas de données disponibles. 


\section{Threats to native freshwater crayfish}

Our data and literature review on historical records provided evidence that freshwater crayfish had a wider distribution in several areas of South Tyrol, which presumably was also the case in North/East Tyrol (FÜREDER and MACHINO, 1999a; FÜREDER and HANEL, 2000). These historical crayfish records were located especially in the broader main valleys, where variable water bodies and courses had developed under natural conditions (from wetlands, ponds, and slow to fast flowing rivers), as well as on higher plateaus. However, in a mountainous area like Tyrol, these flat and exposed areas were ideal for settlement and cultivation. Channel alteration and drainage measures of wetlands were the consequence of increasing land-use activities. Although in most cases the actual cause for crayfish loss and decline is difficult to ascertain, land use and cultivation practices seem to be one of the major threats to native freshwater crayfish. In a former investigation we characterized a selection of 120 watercourses, recorded either as historical/present or potential (when located in the vicinity of a record) crayfish water. Almost $40 \%$ of the stream sectors investigated had little or no riparian vegetation (FÜREDER et al., 2002b).

Land use accompanied with lack of natural habitats or riparian vegetation seems to be the major cause for the decline of populations, given the fact that out of 22 river sectors with crayfish, only five showed some riparian vegetation cover. Most sectors only carry fragmentary to no riparian vegetation. To some extent, FÜREDER et al. (2002c) portrayed riparian vegetation as an indicator of degree of naturalness and habitat availability. On the other hand, the lack of riparian vegetation reflects ineffective buffer strips. Riparian corridors are considered an essential landscape element for protecting freshwater ecosystems from agricultural and industrial effluents (LOWRANCE et al., 1984).

Besides the negative effect of habitat loss, point or non-point contaminants from agricultural use may have threatened native crayfish populations. In preliminary analysis of contaminants we found traces of fertilizers, insecticides and pesticides (L. Füreder, unpubl. data). For a clear coherence between contaminants and the negative effects on crayfish, further experiments are necessary; nevertheless, such evidence exists from an extensive study in the USA (EVERSOLE et al., 1995).

Biological threats, to some extent also a consequence of human activities, include the presence of non-indigenous freshwater crayfish species or high densities of predatory fish. Examples of the introduction of diseases with non-native crayfish is well known in Europe, having resulted in population losses of autochthonous crayfish in many regions (e.g. HOLDICH, 1988; LOWERY and HOLDICH, 1988; GHERARDI and HOLDICH, 1999). Therefore, the two non-indigenous species, Pacifastacus leniusculus and Orconectes limosus, occurring at one location in South Tyrol each (Table II), pose threat to the native populations.

\section{Freshwater crayfish as surrogate species - implications for conservation management}

Lists of threatened species tell us that, on average worldwide, freshwater biodiversity is more threatened than terrestrial (ALLAN and FLECKER, 1993; WILLIAMS et al., 1993; MCALLISTER et al., 1997; Riccardi and RASMUSSEN, 1999). ABELL et al. (2002) summarized from those species considered in the 1996 IUCN (The World Conservation Union) Red List, $20 \%$ of reptiles, $25 \%$ of amphibians, and $34 \%$ of fishes (mostly freshwater) were threatened. At a regional scale, the projected mean future extinction rate for North American freshwater fauna was considered to be about five times greater than that for terrestrial fauna. There is no evidence that this number is too high for Europe.

South Tyrol in particular has experienced a great loss of natural and structurally intact aquatic systems in cultivatable regions, which is only $1 / 6$ of the whole country after 
subtracting rock mass $(>20 \%)$, forest $(\sim 40 \%)$, and mountain pastures $(>20 \%)$. Already in the $19^{\text {th }}$ century infrastructure measures were initiated that enabled the region to become the "Garden of Europe" within the $20^{\text {th }}$ century (FEUERSTEIN, 1999). Exhaustive river regulation and reclamation of land in extensive wetland areas fostered a rapid development of fruit production and viniculture, but also a great loss of natural aquatic systems.

Only from historical landscape descriptions and maps, details about the various freshwater types and also occurring species, among them freshwater crayfish, can the former situation be derived (MÜLLER, 1997). Most of the historical and remaining crayfish sites are located in intensively cultivated areas. Only a few examples, which contain the healthy populations, are surrounded by a less managed environment.

An assessment of habitats based on species inventories always carries problems, as long they are not managed with explicit objectives. In extensively cultivated regions arguments for biological conservation and nature protection often fail because of the existing economic pressures on land. The value of a natural or certain habitat may be justified by high species diversity or by optimal structural environment for a particular species, which seems to be an effective argument for freshwater crayfish.

In North/East Tyrol and South Tyrol, the results of our current crayfish inventories provided water authorities, environmental protection agencies and the public with the alarming fact that compared to their historical distribution freshwater crayfish had dramatically declined. Decreasing populations and population or species extinction have been reported from other European regions, e.g., Ireland (MATTHEWS and REYNOLDS, 1995) and Great Britain (HOLDICH and ROGERS, 1997), Spain (GIL-SÁNCHEZ and ALBA-TERCEDOR, 2002), France (VIGNEUX, 1997), Italy in general (GHERARDI et al., 1999), Germany (BOHL, 1999) and Switzerland (BÜTTIKER, 1987, MICKASCH, 1999), demonstrating that this problem exists at a much larger spatial scale.

In conservation biology often one or a small number of species are used as surrogate species (sensu CARO and O'DOHERTY, 1999) to portray conservation problems. They may be used in various ways, e.g., to indicate the extent of various types of anthropogenic impacts (health indicator species), to track population changes of other species (population indicator species), to locate areas of high biodiversity (biodiversity indicator species), to act as "umbrellas" for the requirements of sympatric species (umbrella species) or to attract the attention of the public (flagship species). Due to their attributes and peculiarities, freshwater crayfish are adequate surrogate species fulfilling the majority of the above stated prerequisites.

Based on our investigations we have started species conservation programs both in Italy and Austria to advance the situation of the native freshwater crayfish A. pallipes, $A$. astacus and $A$. torrentium and to further public awareness, utilizing the paradigm of surrogate species.

Given the results of our study, freshwater crayfish are adequate in indicating ecosystem integrity (= indicator organisms). Healthy populations were preferably found in less degraded systems, intact populations in water bodies with optimal habitat conditions. Anthropogenic impacts were low, reduced or kept low by natural buffer strips or little land use in the catchment.

We observed the decline or the extinction of crayfish in areas with extensive land use. Freshwater crayfish may be used to assess the effects of chemicals, since they are most sensitive to a great variety of fertilizers, insecticides, pesticides (EVERSOLE et al., 1995). In countries with extensive agriculture, like South Tyrol, crayfish population decrease and extinction may be a mirror of the use of harmful substances. Other forms of anthropogenic impacts, like deforestation, reduction of riparian vegetation and river 
regulation, may also have clear negative effects on crayfish habitat and food availability, demonstrated by population decline.

Several other essential prerequisites for the use of freshwater crayfish as indicators of environmental health are the existing knowledge of the species' natural history and ecological factors affecting their population growth rates (HOLDICH, 2001). They may be monitored relatively easily, and have accessible breeding sites, which reduces the costs of monitoring. In several regions or countries they have large populations and a wide geographic range. Together with their sensitivity to human disturbance this makes them effective health indicators of anthropogenically induced environmental change. In ongoing observations, we study the effect of habitat availability and conditions on natural populations.

In this respect, freshwater crayfish can act as umbrella species (CARO and O'DOHERTY, 1999), when used to define spatial and compositional attributes that must be present in a landscape. They may be used to specify size and type of habitat to be protected other than just its location. In two watersheds, each having intact natural crayfish populations, we are currently working on management plans to expand and improve the habitat conditions for crayfish.

As of relatively big size (it is the largest invertebrate in our freshwaters) and of bizarre shape, freshwater crayfish attract the attention of the public, as repeatedly observed. Well known for centuries as proved by our historical information (FÜREDER and MACHINO, 1999a) and now endangered, they are used as "flagships" in conservation (flagship species). We gathered a lot of experience in the species protection programs. Excursions, folders, newspaper articles are now being initiated by a variety of persons and institutions.

Assessing relationships between human land use activities and ecological resources is especially complex in a watershed in which multiple land uses, and interactions among those uses, are likely to be present (DIAMOND et al., 2002). In addition, when only relict populations in a region are present, like in South Tyrol, it is especially difficult to provide necessary correlations between population health and disturbance factors. A study by HARDING et al. (1998) demonstrated that past land-use activities in the 1950s was a better predictor of present-day diversity, whereas riparian land use and watershed land use in the 1990s were comparatively poor indicators. However, given the various adequate attributes of freshwater crayfish as surrogate species (including indicator species, umbrella species and flagship species qualities), ongoing endangered species protection programs will certainly help to advance the crayfish situation combined with freshwater habitat improvements.

\section{ACKNOWLEDGEMENTS}

Help and support of several institutions, public and private persons that provided valuable input into the inventories of freshwater crayfish distribution in the Tyrol provinces, is appreciated. We thank the authorities of Amt für Jagd und Fischerei, Amt für Landschaftsökologie, Amt für Wildbachverbauung, Land- und forstwirtschaftliche Versuchsanstalt Laimburg and Biologisches Labor Leifers for funding and collaborating in past and ongoing projects. We are grateful to two anonymous reviewers and to Catherine Souty-Grosset for the French translation.

\section{REFERENCES}

ABELL R., THIEME M., DINERSTEIN E., OLSON D., 2002. A Sourcebook for Conducting Biological Assessments and Developing Biodiversity Visions for Ecoregion Conservation. Volume II: Freshwater Ecoregions. World Wildlife Fund, Washington, DC, USA. 
ACKEFORS H.E.G., 2000. Freshwater crayfish farming technology in the 1990s: a European and global perspective. Fish and Fisheries 1, 337-359.

ADAMI V. and GASSER M., 1994. Rote Liste der gefährdeten Zehnfußkrebse (Decapoda) Südtirols. In: Abt. f. Landschaft- u. Naturschutz, Autonome Provinz Bozen-Südtirol (Ed.), Rote Listen gefährdeter Tiere Südtirols. Amt für Landschaftsplanung, Autonome Provinz Bozen-Südtirol, Bozen/Bolzano, pp. 23-33 + 348-349.

ALLAN J.D. and FLECKER A.S., 1993. Biodiversity conservation in running waters: Identifying the major factors that threaten destruction of riverine species and ecosystems. BioScience 43, 32-43.

BALDASSI L., 1993. II gambero (Austropotamobius pallipes italicus) nelle acque correnti dell'Alto Adige: distribuzione spaziale in relazione alle caratteristiche ambientali e alla qualità delle acque. Tesi di Laurea, Dipartimento di Biologia Evoluzionistica Sperimentale, Facoltà di Scienze Matematiche, Fisiche e Naturali, Università degli Studi di Biologna, Bologna, pp. 1-74, 6 pl. + 1 map.

BOHL E., 1989. Ökologische Untersuchungen an ausgewählten Gewässern zur Entwicklung von Zielvorstellungen des Gewässerschutzes: Untersuchungen an Flußkrebsbeständen. Bericht Bayerische Landesanstalt f. Wasserforschung 13, pp. $1-237+2$ pl.

BOHL E., 1999. Crayfish stock situation in Bavaria (Germany) - attributes, threats and chances. In: Keller M., Keller M.M., Oidtmann B., Hoffmann R., Vogt G., (Eds.). Freshwater Crayfish 12, Weltbild Verlag, Augsburg, pp. 765-777.

BÜTTIKER B., 1987. Concerning crayfish in Switzerland. In: Goeldlin de Tiefenau P. (Ed.), Freshwater Crayfish 7, Musée Zoologique Cantonal, Lausanne, pp. 2-5.

CARO T.M. and O'DOHERTY G., 1999. On the use of surrogate species in conservation biology. Conservation Biology 13, 805-814.

DIAMOND J.M., BRESSLER D.W., SERVEISS V.B., 2002. Assessing relationships between human land uses and the decline of native mussels, fish, and macroinvertebrates in the Clinch and Powell River watershed, USA. Environmental Toxicology and Chemistry, 21, 1147-1155.

DYNESIUS M. and NILSSON C., 1994. Fragmentation and flow regulation of river systems in the northern third of the world. Science 266, 753-762.

EVERSOLE A.G. and WHETSTONE J.M., SELLERS B.C., 1995. Handbook of relative toxicity values for crayfish. S.C. Sea Grant Consortium.

FEUERSTEIN G., 1999. Grundzüge der Landwirtschaft Südtirols. Der Schlern, 73, 778-784.

FÜREDER L. and HANEL R., 2000. Flusskrebse in Gewässern Nord- und Osttirols: Verbreitung, ökologische Bedeutung und Schutzmaßnahmen. Berichte d. naturwissenschaftlich-medizinischen Vereins Innsbruck, 87, 221-241.

FÜREDER L. and MACHINO Y., 1999a. Past and present situation of freshwater crayfish in Tyrol (Austria and northern Italy). In: Keller M., Keller M.M., Oidtmann B., Hoffmann R., Vogt G. (Eds.). Freshwater Crayfish 12, Weltbild Verlag, Augsburg, pp. 751-764.

FÜREDER L. and MACHINO Y., 1999b. Les écrevisses exotiques dans le Tyrol du Sud (Italie). L'Astaciculteur de France, 61, 2-6.

FÜREDER L., VACHA C., AMPROS, K., BÜHLER S., HANSEN C.M.E., MORITZ C., 2002a. Reference conditions of alpine streams: Physical habitat and ecology. Water, Air \& Soil Pollution, Focus 2, 275-294. 
FÜREDER L., OBERKOFLER B., MACHINO Y., 2002b. Flusskrebse in den Gewässern Südtirols: Verbreitung, ökologische Bedeutung und Gefährdung. Berichte d. naturwissenschaftlich-medizinischen Vereins Innsbruck, 89, 179-200.

FÜREDER L., OBERKOFLER B., HANEL R., MACHINO Y., 2002c. Freshwater crayfish in South Tyrol (Italy): distribution and protection measures of endangered Austropotamobius pallipes. Bull. Fr. Pêche Piscic., 367, 651-662.

GHERARDI F. and HOLDICH D.M., 1999. Crayfish in Europe as alien species. How to make the best of a bad situation. Crustacean Issues 11, A.A. Balkema, Rotterdam, Brookfield, pp. 1-299.

GHERARDI F., BALDACCINI G.N., ERCOLINI P., BARBARESI S., DE LUISE G., MAZZONI D., MORI M., 1999. The situation in Italy. In: Gherardi F., Holdich D.M. (Eds.). Crayfish in Europe as alien species. How to make the best of a bad situation. Crustacean Issues 11, A.A. Balkema, Rotterdam, Brookfield, pp. 107-128.

GIL-SÁNCHEZ J.M., ALBA-TERCEDOR J., 2002. Ecology of the native and introduced crayfishes Austropotamobius pallipes and Procambarus clarkii in Southern Spain and implications for conservation of the native species. Biological Conservation, $105,75-80$.

HARDING J.S., BENFIELD E.F., BOLSTAD P.V., HELFMAN G.S., JONES III E.B.D., 1998. Stream Biodiversity: The ghost of land use past. Proceedings of the National Academy of Sciences, USA 95, 14843-14847.

HELLRIGL K. and THALER B., 1996. Klasse Krebstiere - Crustacea. In: HELLRIGL K., (Ed.), Veröffentlichungen des Naturmuseums Südtirol, Bozen/Bolzano, Band 1: Die Tierwelt Südtirols, pp. 250-261.

HOLDICH D.M., 1988. The dangers of introducing alien animals with particular reference to crayfish. In: GOELDIN DE TIEFENAU P. (Ed.), Freshwater Crayfish, 7, Musée Zoologique Cantonal, Lausanne, pp. XV-XXX.

HOLDICH D.M., 2001. Biology of freshwater crayfish. Blackwell Science, Oxford, pp. 1702 (+ 51 colour plates).

HOLDICH D.M., 2002. Distribution of crayfish in Europe and some adjoining countries. Bull. Fr. Pêche Piscic., 367, 611-650.

HOLDICH D.M. and ROGERS W.D., 1997. The white-clawed crayfish, Austropotamobius pallipes, in Great Britain and Ireland with particular reference to its conservation in Great Britain. Bull. Fr. Pêche Piscic., 347, 597-616.

LOWERY R.S. and HOLDICH D.M., 1988. Pacifastacus leniusculus in North America and Europe with details of the distribution of introduced and native crayfish species in Europe. In: Holdich D.M., Lowery R.S. (Eds.), Freshwater crayfish: biology, management and exploitation. Croom Helm London, pp. 282-308 + 426-479.

LOWRANCE R., TODD R., FAIL J.JR., HEDNRICKSON O.JR., LEONARD, R., ASMUSSEN, L., 1984. Riparian forests as nutrient filters in agricultural watersheds. BioScience, 34, 374-377.

MACHINO Y., 1997. Présence de l'écrevisse de Californie (Pacifastacus leniusculus) en Italie. L'Astaciculteur de France, 52, pp. 2-5.

MATTHEWS M.A. and REYNOLDS J.D., 1995. A population study of the white-clawed crayfish Austropotamobius pallipes (Lereboullet) in an Irish reservoir. Biology and Environment: Proceedings of the Royal Irish Academy 95B, 99-109. 
MCALLISTER D.E., HAMILTON A.L., HARVEY B., 1997. Global freshwater biodiversity: Striving for the integrity of freshwater ecosystems. Sea Wind 11, 1-140.

MICKASCH T.M., 1999. Distribution of Austropotamobius pallipes and Orconectes limosus in the Swiss Midlands. In: KELLER M., KELLER M.M., OIDTMANN B., HOFFMANN R., VOGT G. (Eds.). Freshwater Crayfish, 12, Weltbild Verlag, Augsburg, pp. 796800.

MOOG O. and CHOVANEC A., 2000: Assessing the Ecological Integrity of Rivers: Walking the line among ecological, political and administrative interests. In: JUNGWIRTH M., MUHAR S., SCHMUTZ S. (Eds), Assessing the Ecological Integrity of Running waters, Hydrobiologia 422/423, pp. 99-109.

MÜLLER F., 1997. Die Eyrser Auen - einer der letzten Reste der ursprünglichen Talbodenlandschaften im Vinschgau. Der Schlern, 71, 34-75.

OBERKOFLER B., MACHINO Y., FÜREDER L., 2002. Occurrence of the noble crayfish (Astacus astacus) in Italy. Berichte $d$. naturwissenschaftlich-medizinischen Vereins Innsbruck, 89, 201-210.

ÖNORM M 6232, 1995. Austrian Standards M 6232 - Guidelines for the ecological survey and evaluation of flowing surface waters. - Österreichisches Normungsinstitut, Vienna, pp. 1-38.

PRETZMANN G., 1994. Rote Liste der Zehnfüßigen Krebse (Decapoda) und Schwebegarnelen (Mysidacea) Österreichs. In: GEPP J. (Ed.), Rote Listen gefährdeter Tiere Österreichs. Grüne Reihe, Band 2, Bundesministerium für Umwelt, Jugend und Familie, Wien, pp. 31-34 + 279-282 + 336 .

RICCARDI A. and RASMUSSEN J.B., 1999. Extinction rates of North American freshwater fauna. Conservation Biology, 13, 1220-1222.

SKURDAL J. and TAUGBOL T., 2001. Crayfish of commercial importance. Astacus. In: HOLDICH D.M. (Ed.), Biology of freshwater crayfish. Blackwell Science, Oxford, pp. 467-510.

VIGNEUX E., 1997. "Lightning survey" on the astacology of the genus Austropotamobius in Europe. Bull. Fr. Pêche Piscic., 347, 589-594.

WILLIAMS J.D., WARREN M.L.JR., CUMMINGS K.S., HARRIS J.L., NEVES R.J., 1993. Conservation status of freshwater mussels of the United States and Canada. Fisheries 18, 6-22. 